\title{
Forms and Drivers of Conflicts between Farmers and Pastoralists in Kilosa and Kiteto Districts, Tanzania
}

\author{
Parit Luka Saruni ${ }^{1}$, Justin Kalisti Urassa ${ }^{2}$ and George Chamungwana Kajembe ${ }^{3}$ \\ 1. Department of Social Studies, Mwalimu Nyerere Memorial Academy, P.O. Box 9193, Dar es Salaam, Tanzania \\ 2. Department of Policy, Planning, and Management, College of Social Sciences and Humanities (CSSH), Sokoine University of \\ Agriculture, P.O. Box 3024, Chuo Kikuu, Morogoro, Tanzania \\ 3. Department of Forest Resources Assessment and Management, College of Forestry, Wildlife and Tourism, Sokoine University of \\ Agriculture, P.O. Box 3013, Chuo Kikuu, Morogoro, Tanzania
}

\begin{abstract}
Farmer-pastoralist conflicts represent a significant challenge for rural communities and the Tanzanian government. The study objectives were to (i) determine existing forms of conflicts and (ii) identify drivers underlying resource use conflicts. The manuscript is based on a study that adopted a cross-sectional research design whereby data were collected from 373 randomly selected respondents from Kilosa and Kiteto districts, Tanzania, while primary data were collected through interviews, observations and focus group discussions, secondary data were gathered from government reports and newspapers. Quantitative data were analysed using the Statistical Package for the Social Science (SPSS) version 20.0. Descriptive statistical analysis was carried out for quantitative data. Factor analysis was used to extract component factors on drivers and forms of conflicts, whereas content analysis was used to analyse the qualitative data. Generally, study results show that there were three main forms of conflict namely farmers versus pastoralists over village boundaries; farmers versus pastoralists over livestock routes and farmers versus farmers over the land. In addition, four main drivers underlying resource use conflicts were identified namely crop damage by livestock; inefficiency of government officials in taking action to diffuse conflicts; excessively large herds of cattle and corruption. It is therefore recommended that pastoralists should be provided with essential services such as water in order to minimize movement of their livestock herds from their designated villages to other areas in search of water. This would, in the long run, minimise crop damage which has been a major source of conflict. In addition, proper land use planning is recommended to minimize resource use conflicts.
\end{abstract}

Key words: Forms, drivers, conflicts, pastoralists, farmers, Kilosa and Kiteto.

\section{Introduction}

Competition for land between and within various user groups has been bothering mankind since time immemorial [1]. The emergence of these conflicts could be traced back to the Biblical era when the Holly Bible gives an account of conflicts. And there was strife between the herdsmen of Abraham's cattle and the herdsmen of Lot's cattle, and the Canaanites and the Perizzites dwelled then in the land (Genesis 13:7, King James Bible). Benjaminsen et al. [2] refers to the biblical story of the conflict between Cain and Abel, which led to the murder of the latter by the

Corresponding author: Parit Luka Saruni, Ph.D., research field: natural resource governance. former, as an archetypal example of the tension between sedentary farmers and migrating pastoralists.

For many years, sub-Saharan Africa has experienced complex and several unresolved conflicts between and among farmers and pastoralists. For instance, in South Sudan, the conflicts are frequent and take the form of inter and intra-communal conflicts, which are mainly driven by cattle raids [3]. Other drivers of conflicts include historical tensions and a tendency to resolve these through violent means, increasing competition of access to grazing land and water, declining influence of traditional authorities, weakling of state institutions, promotion of a culture of impunity, heightened demand and competition for land and appropriation of large tracts of land for 
agricultural expansion as well as inflation in the "bride price” among the pastoralists [3]. A similar situation is reported in Ethiopia, where different forms of natural resource use conflicts can be identified among the pastoralists and farmers. According to Wood [4], the forms inter alia include inter-group conflicts-these are conflicts between different ethnic groups; intra-group conflicts-these are conflicts between different socio-economic groups within an ethnic group; intra-state conflicts-these are conflicts between the state and people, and intra-government conflicts-these are conflicts between different groups and organisations.

In Tanzania, long standing conflicts and clashes between farmers and pastoralists are now a serious national challenge, which takes political and humanitarian dimensions. Among the most notable bloody clashes pitying farmers against pastoralists occurred in Kilosa district in December 2000, whereby 38 people were killed among them women and children [5]. These conflicts have generally been driven by disputes over boundaries between pastoralists in Mabwegere village against farmers in six neighbouring villages, namely, Mfulu, Dumila, Mambegwa, Matongoro, Mateteni and Mbigiri [6].

Other, clashes occurred as recently as January 12th, 2014 in Kiteto which led to the death of 10 people leaving 20 others injured, 60 houses burnt down and a number of properties including six motorcycles and 53 bicycles destroyed [7]. Since then, more than 30 people have been killed and about 200 injured in the clashes [8]. These clashes were ignited by the eviction of invaders from Emboley Murtangos, which is a community based natural resource management area ${ }^{1}$ (CBNRM). This area was set aside by seven adjacent

\footnotetext{
${ }^{1}$ Emboley Murtangos is CBNRM set aside by the seven villages, i.e., Engusero Sidai, Emarti, Kimana, Loltepes, Namelock, Ndirgish and Nhati in 2003 desired to protect their wildlife, vegetation and to provide grazing for their livestock. Source CBOs operating in the Kiteto district; KINAPA, CHORDs, MWEDO and NADUTARO between August-October 2015.
}

villages $^{2}$ between 2002 and 2003 [9]. Moreover, as reported by Askew et al. [9], the disputed CBNRM between farmers and pastoralists covers roughly 3,200 $\mathrm{km}^{2}$, of which $15 \mathrm{~km}^{2}$ are wetlands and salt licks, which are resources of crucial importance for livestock keeping.

Apart from the aforementioned conflicts, Morogoro has also experienced typical intra-group conflicts involving members of the same ethnic group, Maasai against fellow Maasai with respect to ownership of small ranches. The concept of small ranches emerged in 2003 following the privatisation of Dakawa ranch which is officially known as Farm No. 299 covering 52,502 ha. According to Hakiardhi [10], the ranch was divided into plots and allocated to private companies and the local people including the Maasai. During the allocation, the private investors obtained 2,479 ha, Mtibwa Sugar Company had 30,000 ha, Wami Luhindo village in Mvomero had 1,997 ha, small-scale farmers had 5,000 ha, Mvomero District Council had 3,000 ha, indigenous livestock keepers got 5,019 ha, and modern livestock keepers got 5,000 ha, which were meant to support modern livestock keeping. In addition, the 5,019 ha for indigenous livestock keepers were further subdivided into small plots of 100 ha which were referred in Kiswahili as ranchi ndogondogo (mini ranches) leading to the concept of small ranches, and these were later sold to the Maasai pastoralists. Nevertheless, following this land subdivision, the wealthy pastoralists were accused of grabbing a number of small ranches leaving their fellow Maasai without any pieces of land. The majority of the pastoralists who did not get land within the small ranches migrated to Kilosa and Morogoro districts.

Tanzania has approximately 21 million heads of cattle, the largest number in Africa after Ethiopia and Sudan. Livestock contributes to at least $30 \%$ of the country's agricultural GDP [11]. Small-scale farmers

\footnotetext{
${ }^{2}$ Engusero Sidai, Emarti, Kimana, Loltepes, Namelock, Ndirgish and Nhati
} 
produce more than $90 \%$ of the food consumed in the country. Of the country's 94.5 million hectares, only about half, that is, 44 million hectares are arable land [12]. Consequently, Tanzania's agriculture is dominated by small-scale subsistence farming and approximately $85 \%$ of the arable land is used by smallholders who cultivate between 0.1 ha and 2.0 ha and traditional agro-pastoralists who keep an average of 50 heads of cattle [13]. Based on these statistics, farmers could be referred to people whose greater percentage of income comes from crop production; but according to King [14], farmers are the people who are involved in the cultivation of land for growing various types of crops. Normally, farmers are differentiated from peasants by the acreage of land cultivated. Peasants are considered to be those who cultivate farms for subsistence mainly to meet their basic needs. Yet, farmers have the ability to produce a surplus, as they have bigger areas of farm lands as opposed to peasants. In this study, therefore, land use conflict is a phenomenon which involves both farmers and peasants against pastoralists. While pastoralists are people who depend on livestock and whose significant level of income of greater than 50\% comes from livestock keeping with some form of mobility as a characteristic in pastoralism [15]. Thus, pastoralism refers to a socio-economic system which involves raising and herding of livestock [14]. In Tanzania, there are several ethnic groups that practise one or another form of pastoralism from pure pastoralism (Barbaig and Maasai) to transhumance (Ntuzu-Sukuma) and agro-pastoralism to more or less settled agro pastoralism (Sukuma, Gogo, Kaguru and Nyaturu).

Several studies in sub-Saharan Africa, Tanzania included have looked into the causes, effects and management of these conflicts [2, 14-19]. Nevertheless, little has been done to examine the linkage between forms and drivers of natural resource use conflicts among farmers and pastoralists, though, in the recent past, these conflicts have been escalating.
The magnitude of these conflicts particularly in Kilosa district has prompted the government through the Ministry of Lands, Housing and Settlement Development to appoint a High Court judge to investigate the conflicts pitying pastoralists in Mabwegere village against farmers in six neighbouring villages [20]. Therefore, determining the drivers and forms of conflicts will eventually equip different stakeholders including policy makers with the requisite knowledge/information which will then enable them to devise specific interventions to address the existing forms of conflicts.

As stated earlier, several studies in Tanzania have focused on the causes of conflicts between farmers and pastoralists and that empirical data on the forms and drivers of these conflicts are scanty [21, 22]. Therefore, the current study on which this manuscript was based was specifically aimed at (i) ascertaining the existing forms of conflicts; (ii) identifying the drivers underlying resource use conflicts in Kilosa and Kiteto districts in Tanzania.

\section{Theoretical Framework}

There is evidence in human society of the existence of different forms of conflicts. On the one hand, psychology has espoused on intra-personal forms of conflict whereby a person's situation is manifest through anger, depression, confusion, frustration all of which eventually could result to erratic behavior such as suicide [23]. This form of conflict is also known as "man against self" [24] and is characterised by addictive habits such as smoking, drug use, alcoholism, and lying. On the other hand, sociology identifies intra-personal as well as intragroup forms of conflict. This form of conflict, according to Folarin [25], is a disagreement that takes place between two or more sectarian or religious groups, ethnic groups, inter-communities or interest groups such as farmers and pastoralists. This article deals with inter-community conflicts and their drivers. However, different approaches might be used to explain the 
potential drivers of natural resource use conflict in the society. For example, Mpangala and Mwansasu [26] and Bernauer et al. [27] link natural resource use conflicts in Africa, to the struggle for political and economic resources for personal interests. Homer-Dixon [28] and Barnett and Adger [29], link environmental scarcity to natural resource use conflict. They argue that, although environmental scarcity is not a major factor behind most of these conflicts, it helps to generate chronic and diffuse subnational violence. Moreover, environmental scarcity is expected to exert influence in the future because of increasing human population and higher per capita resource consumption rates. Collier-Hoeffler analytical model of conflicts provides a strong association between the size of population and conflicts. It is argued that large populations are more prone to conflicts than small population. Although Collier-Hoeffler [30] and De Soysa [31] linked natural resource use conflicts to cultural aspects such as ethnicity and religiosity. But some theories identify grievances of groups as a primary reason for violent conflicts. A review of some theoretical perspectives in this paper shows that there is no single model that can explain the drivers of resource use conflicts. Thus, application of different models in the analysis of forms and drivers of conflict relatively yield better results.

\section{Methodology}

\subsection{Study Areas}

The study was conducted in Kilosa and Kiteto districts in Morogoro and Manyara regions, respectively, as shown in Fig. 1 . The selection of the study districts was based on the following criteria: prominence, persistence and severity of conflicts in terms of loss of human life, property damage and presence of a higher population of farmers and pastoralists. In the government and development reports and in national newspapers, the districts are often referred to as areas of land scarcity and conflicts
[32].

Kilosa is one of the six districts in Morogoro region, Tanzania covering $14,265 \mathrm{~km}^{2}$ out of which 4,286 $\mathrm{km}^{2}$ are under wildlife conservation and forests reserves. The conservation areas cover almost one third of the district's total area. Mikumi National Park covers $3,230 \mathrm{~km}^{2}$ or $22.7 \%$ of the district. Forests reserves cover $1,056 \mathrm{~km}^{2}$ or $7.4 \%$ of the district [5]. Kilosa borders Kiteto and Kilindi districts to the north, Mvomero and Morogoro districts to the east, Mpwapwa and Kongwa districts to the west and Kilombero and Kilolo districts to the south [33]. As reported by the National Bureau of Statistics (NBS) 2016-2017 population projections Kilosa district had 492,879 people [34]. In Kilosa, rainfall varies substantially from year to year. Generally, the rain falls in two seasons: short rains in November to December and long rains from mid-February through April. Ethnic groups found in the district include Kaguru, Sagara, Vidunda, Parakuyo Maasai, Barabaig, Gogo and Sukuma [2].

Kiteto is a district in Manyara region, Tanzania. The district has semi-arid conditions and covers over $16,305 \mathrm{~km}^{2}$ with rainfall ranging from $450 \mathrm{~mm}$ to 650 $\mathrm{mm}$ per annum [32]. Rainfall regimes in the district are bimodal, with a short and long rain seasons. The short rains begin in October through December while the long rains start in February and end up in May [33]. According to the Tanzania National Bureau of Stastics (NBS), 2016-2017 population projections Kiteto district had 286,741 people [34]. The existing land conflicts between farmers and pastoralists in Kiteto district started way back in 2003. Ever since at least 30 people have been killed and about 200 were injured in the clashes [35].

\subsection{Research Design, Sampling Procedures and Sample Size}

A cross-sectional research design was adopted for the study. The design allows collection of both qualitative and quantitative data in a short period of time 
Forms and Drivers of Conflicts between Farmers and Pastoralists in Kilosa and Kiteto Districts, Tanzania
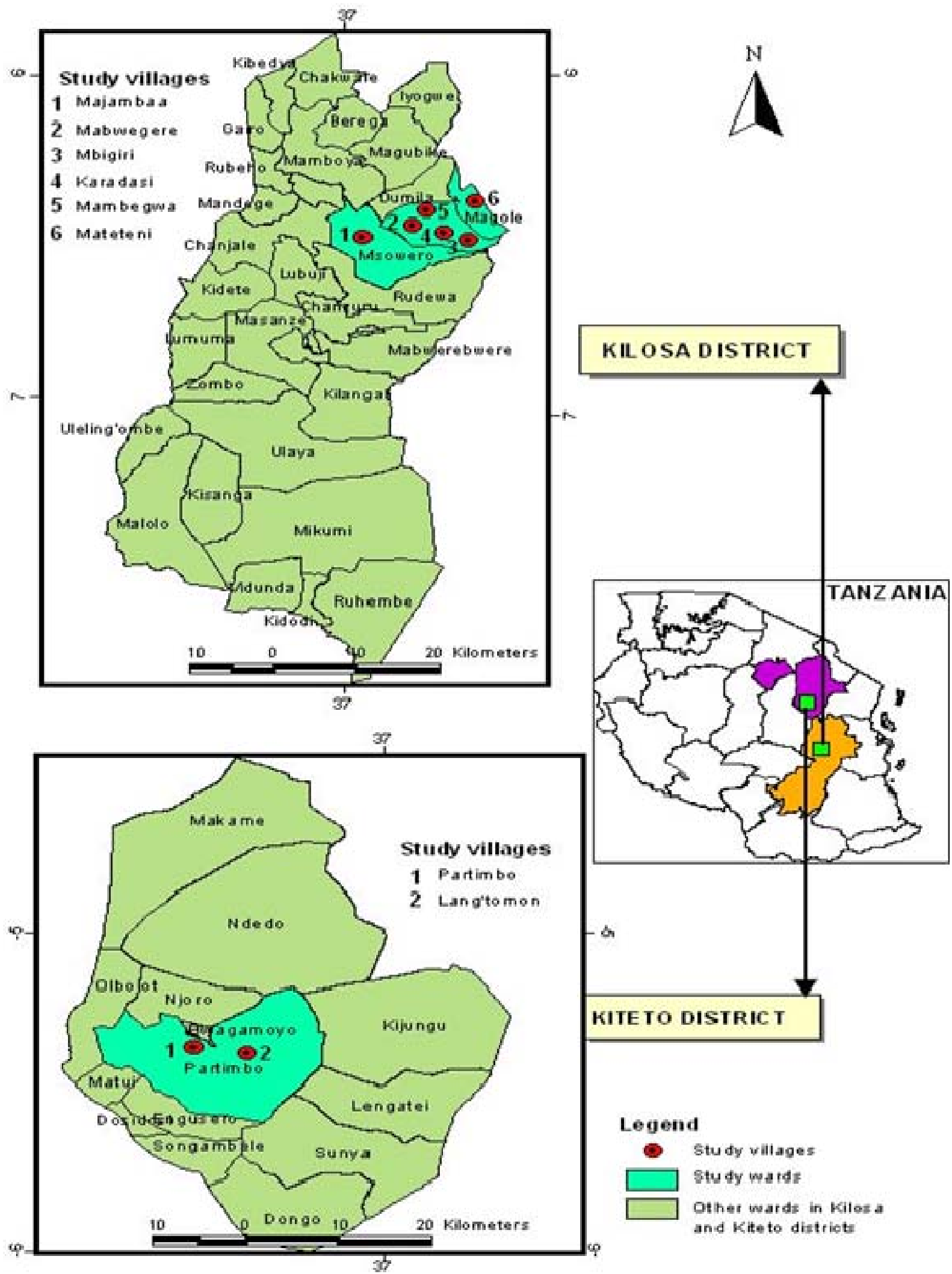

Fig. 1 A map of the study areas. 
[36, 37]. The study population comprised all households within the land use conflict-affected areas. According to Ref. [38], the population size for the wards which were affected by the conflicts in Kilosa and Kiteto were 45,687 and 38,649, respectively. The sample size determination formula was adopted from Ref. [39]. In Kiteto district, Partimbo division whose majority of villages were severely affected by conflicts between farmers and pastoralists was given priority after a detailed discussion with the District Council Authorities. Respondents from study districts were determined using a proportionate sampling formula by Bryman [40] as presented in Appendix 1. The study employed both probability and non-probability sampling procedures. Overall, 373 respondents were selected randomly. Using proportionate sampling formula 145 and 228 respondents were randomly selected in Kiteto and Kilosa, respectively. Though the pastoralists preferred the head of the homestead, enkan'g ${ }^{3}$ or boma ${ }^{4}$ to participate in the interview, the researcher took the initiative to explain to the head of the enkan'g the importance of individual household members to participate in the study which they agreed. The heads of the Maasai pastoralist homesteads were meant to understand that in an event of deadly conflicts the effects were mostly felt at the household level than at the entire 'boma' level.

The study areas including districts and villages, participating local organizations and key informants were purposively selected based on the frequency and perceived damage caused by resource use conflicts. Cluster sampling was used to select farmers and pastoralists because they were the main conflict actors. Since conflict is a very sensitive phenomenon, at some point in time snowball sampling technique was used to locate those respondents who were perceived to

\footnotetext{
${ }^{3}$ Maasai enclosure for livestock surrounded by many hurts fenced with thorn bushes to safeguard them from theft and attacks from wild animals.

${ }^{4} \mathrm{~A}$ Kiswahili word meaning a livestock enclosure and is comprised by more than one household.
}

have knowledge regarding conflict situations and those who had suffered severe damages or effects caused by the conflicts with an intention of getting some detailed case studies. These included farmers and pastoralists whose houses were set ablaze, property destroyed and victims of any form of abuse such as rape, individuals with sustained body injuries and those who had lost family members through death as a result of land disputes between farmers and pastoralists. In addition, snowball sampling was used to track those people who had moved out of the study areas due to conflicts in which case random sampling could not have allowed their participation in the study.

\subsection{Data Collection}

In order to address the research questions, both primary and secondary data were collected. Qualitative data were collected using informal discussions, observations, interviews and focus group discussions (FGDs). Twelve (12) FGDs were held with the participants. These comprised six (6) FGDs in each study district. Each FGD involved eight to twelve (8-12) participants. However, for each district, there were three separate groups, those composed of farmers and those of pastoralists and groups with a combination of farmers and pastoralists. The purpose was to enable each specific livelihood group to freely express their needs and concerns. Direct observation techniques in data collection featured on land and herd sizes owned, livestock routes to water points, sources of water, distance to the pasture and the mode of livestock grazing, persons involved in tending livestock, those whose property was destroyed during conflicts, abandoned farms, burnt houses, farmer and pastoralists' day to day socio-interactions. Quantitative data were collected through a household questionnaire, whereby information on a socio-demographic characteristic of the respondents and forms and drivers of conflicts among farmers and pastoralists were collected. Key informants to the study included among others: the district 
commissioner (DC), the district executive director (DED), officer commanding district (OCD), leaders of community based organisations, traditional leaders 'Laigwanak' among the Maasai community, local government staff such as extension officers and the elderly and influential people in the study villages. A checklist containing questions in tandem with the theme of the study was used as an interview guide in the FGDs and key informant interviews. Secondary data were collected from diverse credible sources, including government reports; existing non-governmental organisations (NGOs) and community based organisations (CBOs) reports and newspapers. Information which was collected from the aforementioned sources included incidents of the occurrence and extent of property damage as a result of resource use conflicts. Other sources included court testimonies, criminal records from the police, including reports on the malicious damage of property and records on the unlawful land acquisition from the community without following the legal procedures.

\subsection{Data Analysis}

The study's unit of analysis was the household. Therefore, the descriptive statistical analysis was used to determine the socio-economic characteristics of the respondents. Multiple responses and factor analysis mainly principal component analysis (PCA) was used to determine the forms and drivers of resource use conflicts. The assumption used in these analysis techniques was based on the fact that only components with eigen values greater than one should be employed. Therefore, a PCA was used to extract component factors on the drivers of farmers-pastoralists conflicts in the study areas. Factor Analysis is a multivariate technique which is employed to establish the interrelationship between variables as well as in explaining the variables in terms of their common factors. Content analysis was used to organise qualitative information into similar themes for the purpose of generating some meaningful information. According to Bryman [40], the content analysis comprises searching for underlying themes in the material being analysed.

\section{Results and Discussion}

\subsection{Socio-economic Characteristics of the Surveyed Households}

Basic descriptive demographic and socio-economic data are represented in Table 1. In both Kilosa and Kiteto districts, the majority of the respondents were married. According to Mutayoba [41], stable families would concentrate more on production compared to unstable ones and hence could likely influence agricultural production. However, separation and divorce rate was higher among farmers possibly due to seasonal employment away from home which allows them to seek temporary sexual partners during farming season. Among the farmers, female respondents were more represented as opposed to pastoralists who portrayed complete male domination. Farmers have slightly higher levels of formal education compared to pastoralists suggesting that the latter are less informed about modern livestock techniques which could assist them to minimize natural resource use conflicts. According to Saruni [18], despite the adequacy of primary schools in most pastoral villages, pastoralists are generally reluctant to send their children to school, because either, they have inadequate knowledge on the importance of education, or stakeholders in the education sector have failed to effectively play their role hence denying the community the benefits of universal primary education (UPE).

Another plausible reason could be that pastoralist communities seem to rely more on family labour for livestock keeping activities that is why they don't send their children to school. Generally, there were more pastoralists shifting towards crop cultivation than farmers who were shifting to livestock keeping. A discussion with key informants revealed that farmers 
Table 1 Socio-economic characteristics of respondents.

\begin{tabular}{|c|c|c|c|c|c|c|}
\hline \multirow[b]{2}{*}{ Characteristic } & & \multicolumn{2}{|c|}{ District } & \multicolumn{2}{|c|}{ Respondents (\%) } & \multirow[b]{2}{*}{$\begin{array}{l}\text {-Overall (\%) } \\
100(\mathrm{n}=373)\end{array}$} \\
\hline & & $\begin{array}{l}\text { Kilosa (\%) } \\
\mathrm{n}=228 \\
\end{array}$ & $\begin{array}{l}\text { Kiteto (\%) } \\
\mathrm{n}=145\end{array}$ & $\begin{array}{l}\text { Pastoralists } \\
\mathrm{n}=143\end{array}$ & $\begin{array}{l}\text { Farmers } \\
\mathrm{n}=230\end{array}$ & \\
\hline \multirow[t]{6}{*}{ Marital status } & Married & $80.9(74.8)$ & 90.7 (79.1) & 84.6 & 76.5 & 80.5 \\
\hline & Widowed & 13.5 (7.9) & $3.7(1.1)$ & 9.8 & 5.2 & 7.5 \\
\hline & Single & $3.4(7.2)$ & 3.7 (9.9) & 3.5 & 8.3 & 5.9 \\
\hline & Living together & $0.0(3.6)$ & $1.9(1.1)$ & 0.7 & 2.6 & 1.7 \\
\hline & Separated & $1.1(3.6)$ & $0.0(7.7)$ & 0.7 & 5.2 & 3.0 \\
\hline & Divorced & $1.1(2.9)$ & $0.0(1.1)$ & 0.7 & 2.2 & 1.4 \\
\hline \multirow[t]{2}{*}{ Sex } & Male & 80.9 (79.9) & $87.0(82.4)$ & 31.9 & 49.9 & 81.8 \\
\hline & Female & $19.1(20.1)$ & $13.0(17.6)$ & 6.4 & 11.8 & 18.2 \\
\hline \multirow[t]{5}{*}{ Education level } & No schooling & $65.2(27.3)$ & $42.6(25.3)$ & 56.6 & 26.5 & 41.6 \\
\hline & Primary education & 16.9 (66.9) & $33.3(63.6)$ & 23.1 & 65.7 & 44.3 \\
\hline & Adult education & $10.5(2.2)$ & $9.3(2.2)$ & 9.8 & 2.2 & 6.0 \\
\hline & Post-secondary education & $5.6(0.0)$ & $7.4(1.1)$ & 6.3 & 0.4 & 3.4 \\
\hline & Secondary education & $2.2(3.6)$ & $7.4(7.4)$ & 4.2 & 5.2 & 4.7 \\
\hline \multirow[t]{3}{*}{ Age category } & 20-35 years & $15.8(15.8)$ & $13.3(22.2)$ & 37.1 & 25.8 & 31.5 \\
\hline & $36-50$ years & $15.8(29.4)$ & $39.1(53.9)$ & 41.3 & 45.8 & 43.5 \\
\hline & Above 50 years & $68.4(54.8)$ & $47.6(23.9)$ & 21.6 & 28.4 & 25.0 \\
\hline Household size & Mean household size & $5.2(8)$ & $6.5(5.8)$ & 7.0 & 5.0 & 5.8 \\
\hline
\end{tabular}

Numbers in the parenthesis represent socio-economic characteristics for farmers in both Kilosa and Kiteto districts.

refused to engage in livestock keeping for fear of theft by Maasai pastoralists. Moreover, this could further increase farmers-pastoralists conflicts due to competition for grazing land and water resources. In addition, farming and pastoralism were portrayed as activities for the elderly as these mainly involved respondents above 35 years old. On average, pastoralists had large household size compared to farmers implying that the former had enough labour to be employed in livestock rearing.

\subsection{Forms of Conflicts in the Study Areas}

Literature shows that there are different forms of resource use conflicts in Africa [18, 42]. Overall, the study identified eight forms of conflicts in the study area as shown in Table 2. And using the PCA, three main forms of conflicts were identified based on eigen values. These were farmers versus pastoralists over village boundaries (2.220); farmers versus pastoralists over livestock routes (1.73); farmers versus farmers over land (1.28). Similarly, Kisoza [42] identified three categories of resource use conflicts in Kilosa, namely, inter-ethnic conflicts, inter-village conflicts and village versus government agencies conflicts. However, in Kagera, Kisoza et al. [43] reported four forms of conflicts namely, farmers against pastoralists, farmers against farmers, farmers against investors and farmers against government agencies.

The findings of the current study differ from the findings of the aforementioned studies because Kilosa has all major land use systems found in Tanzania namely, leased estate farms, state ranches, national park and reserved catchment forest, smallholder subsistence farming system and pastoralism [43] that could possibly allow for more diversity, thus, conflict among various stakeholders. Similarities in the forms of conflicts across two different geographical locations imply a lack of genuine efforts by different stakeholders including the local government to address the factors underlying the conflicts.

Conflicts of farmers versus pastoralists over village boundaries were reported both in Kilosa and Kiteto districts. In Kilosa district, for instance, the study found the existence of boundary disputes between 
Table 2 Forms of conflicts in the study areas $(n=373)$.

\begin{tabular}{lllll}
\hline Forms of natural resource use conflicts & $\begin{array}{l}\text { Respondents } \\
(\%) \\
\mathrm{n}=373\end{array}$ & Eigen value & \% of variance & $\begin{array}{l}\text { Cumulative \% } \\
\text { of variance }\end{array}$ \\
\hline Farmers versus pastoralists along village boundaries & 81.1 & 2.221 & 27.77 & 27.77 \\
Farmers versus pastoralists over livestock route & 98.4 & 1.732 & 21.66 & 49.44 \\
Farmers versus farmers over land & 24.1 & 1.282 & 16.02 & 65.44 \\
Farmers-pastoralist versus investors conflicts over land & 55.0 & 0.938 & 11.72 & 77.16 \\
Farmers pastoralists versus conservation authorities & 34.9 & 0.664 & 8.30 & 85.46 \\
Household against a family member over land inheritance & 24.4 & 0.604 & 7.55 & 93.01 \\
Pastoralists versus pastoralists & 24.1 & 0.475 & 5.94 & 98.94 \\
Residents versus village government over settlement & 23.6 & 0.085 & 1.06 & 100.0 \\
\hline
\end{tabular}

Mabwegere village and other neighbouring villages of Magole, Mfulu, Karadasi, Mateteni and Mbigiri.

The results from FGDs show that these boundary disputes are politically driven. This argument is based on the fact that Mabwegere was officially registered as a grazing area in December 8th, 1989 and acquired a title deed in June 10th, 1999. However, there has been some interference from political leaders, who have been in favour of farmers, thus, allowing them to trespass legally the set boundaries. This was manifested by increased farming activities in the area, thus, leading to competition over the use and control of land between farmers and pastoralists. A similar form of conflict was reported in Kiteto, pitying two villages, namely, Namelock and Kimana, with the major driver being a violation of legally recognised land boarders. This was further reported to have been driven by corrupt village officials and political leaders, and, mainly councillors who illegally sold village land to outsiders at the expense of local communities. The persistence of conflicts in Kilosa and Kiteto districts suggests a lack of adequate knowledge about pastoralism as a system of livelihood. In addition, the district councils in the study areas lack strategies of transforming pastoralism into the modern system of livestock keeping.

Farmers-pastoralists conflict over livestock routes was common in the villages, where farms are established along water points, but, most prevalent in such villages such as Magole and Kitete wards in Kilosa district where crops are under irrigation. These conflicts occurred because when pastoralists try to get access to crops residues from the farms their livestock always destroy crops in the neighbouring farms. Kajembe et al. [16] and Abbass [44] ranked crop damage as the major cause of many conflicts. Natural resource use conflicts were also reported in those areas where farms are found along the traditional livestock routes. This type of conflict was reported to be a common phenomenon in Kimana village in Kiteto district. During the survey, livestock was observed passing along the routes, which were too close to farm lands as they found their way towards water points. Equally important, farmers have established their permanent residences and vegetable gardens adjacent to water points which undermine further the rights of pastoralists to have access and use of the water resources. This suggests that lack of clearly recognized livestock routes subject crops to livestock damage leading to conflicts. Conflicts between farmers over land use were triggered by multiple allocations or leasing of same farm lands to more than one person and trespassing. The double allocation trend was caused by unscrupulous village officials who would stop at nothing in bending the rules for personal gains. In Kiteto, for example, the respondents cited examples of leasing of a single farming plot to more than one person and hence triggering conflicts. According to Saruni [18], farmers' conflicts over farm plots significantly increase the likelihood of resource use conflicts particularly in the villages where farming is the predominant activity and 
the majority of land users are farmers.

\subsection{Drivers of Farmers-Pastoralists Conflicts in the Study Areas}

Study results (Table 3) show drivers to resource use conflicts between farmers and pastoralists in the study area. The drivers include government officials' reluctance to take timely actions to defuse conflicts, crop damages by livestock, excessively large herds of cattle and the tendency of pastoralists corrupting government officials.

However, according to Ref. [19], it is important to note that no single factor can adequately explain the prevalence of conflicts between farmers and pastoralists; instead, it is the combined effects of these factors which can be held responsible for the worsening situation. Table 3 shows further the respective eigen values and the percentage of variance for different drivers. The results in Table 3 show further that only four components had eigen values of greater than one with the fourth factor representing the a ccumulative variance of $65.0 \%$.

\subsubsection{Crop Damage by Livestock}

The study findings showed that leading drivers of conflicts between farmers and pastoralists include crop damage by livestock and this had an eigen value of 2.502. However, the incidences of crop damage were either accidental or deliberate in nature. Accidental incidences were those related to cattle straying into farming plots, which implies that there was improper tending/herding of cattle, blocking of livestock routes to the existing water points and weak fencing ${ }^{5}$ made at kraals or "bomas". Weak fencing encouraged, livestock to often escape at night, stray into farms and destroy crops. The deliberate damage of crops involves feeding livestock on late maturing crops such as pigeon peas. Chronic conflicts between the two groups were reported to be experienced towards the harvesting season. Pigeon peas according

\footnotetext{
${ }^{5}$ Researcher's observation on the nature of fencing of the Kraals or "bomas", where cattle are confined at night to safeguard them against theft and attacks from wild animals.
}

to pastoralists are a good fodder during drought periods. On the other hand, pigeon pea is a more climate friendly crop than is the case with ordinary beans. Thus, the tendency by pastoralists turning food crops into fodder has of late increased the friction between the two groups. Usually, after harvesting all crops, pigeon peas are left in the field, until they are fully mature before harvesting. Unfortunately, this happens during the dry spell when pastoralists are desperately in need of pastures to feed their stock. This is when some of the pastoralists get tempted to feed their cattle on crop residues available in the farms, and in so doing they destroy the pigeon peas. Similar studies have associated crop damage by livestock to conflict through increased food insecurity [45] and competition for wetlands and river valleys during dry spells [46]. In the current study, the respondents reported that lack of good land use planning had increased the chances of crop damage by livestock. These results are backed by police records which linked major reported cases of conflicts to crop damage by livestock resulting in fights between farmers and pastoralists. According to the police, these incidences are usually treated as criminal offences due to the malicious nature of the damage of property or crops. The exception is when one is seeking for compensation for the damage caused by the offender who is charged under civil case procedures.

4.3.2 Inefficiency of Government to Timely Take Action to Defuse Conflicts

Government officials' inefficiency to take timely action in defusing conflicts was also reported by the majority (80.2\%) of the respondents, and this had an eigen value of 1.455 as shown in Table 3. With regards to this driver of natural resource use conflict, an accusing finger was directly pointed to the village governments which were seen to propagate the prevailing conflicts due to lack of involvement of the people in major and various land use decisions including land allocation. During the FGDs, it was reported that village leadership had always tried their 
Table 3 Drivers of farmers-pastoralists conflicts in Kilosa and Kiteto districts $(n=373)$.

\begin{tabular}{llllc}
\hline Drivers of conflicts & Eigen values & \% of variance & \multicolumn{2}{c}{$\begin{array}{l}\text { Cumulative \% of } \\
\text { the variance }\end{array}$} \\
\hline Crop damage by livestock & 2.502 & 22.746 & 35.977 & 96.5 \\
Inefficiency of government to timely take action to defuse conflicts & 1.455 & 13.231 & 46.780 & 80.2 \\
Excessively large herd of cattle & 1.188 & 10.803 & 56.161 & 69.7 \\
Pastoralists corrupting government officials & 1.032 & 9.382 & 65.040 & 70.0 \\
Farmers' forcibly confiscating cattle & 0.977 & 8.879 & 73.389 & 88.2 \\
Warring behaviours of herders warriors (morans) & 0.918 & 8.349 & 80.957 & 65.4 \\
Herders violating boundaries & 0.832 & 7.568 & 86.866 & 83.9 \\
Farmers disregarding village boundaries & 0.650 & 5.909 & 96.396 & 51.7 \\
Ethnic-based hatred between farmers and pastoralists & 0.547 & 4.971 & 91.837 & 60.6 \\
Heavy penalties demanded by farmers for crop damages & 0.501 & 4.559 & 100.000 & 89.5 \\
Government officials favouring farmers & 0.396 & 3.604 & 22.746 & 89.3 \\
\hline
\end{tabular}

best to handle the farmers-pastoralists conflict but they did not get any support from higher authorities ${ }^{6}$. This observation suggests that existence of a divided government position towards natural resource use conflict between farmers and pastoralists. According to Ref. [19], the traditional conflict resolution machinery at the village level has been weakened partly by the emergence of statutory approaches based on formal procedures, and on the other hand, by the influx of pastoralists who do not share the values and beliefs upon which these mechanisms are anchored. The above observation is echoed by Pantuliano [47] who argues that in sub-Saharan Africa, land conflicts are proving more difficult to solve because traditional instruments of reconciliation, such as compromise have been rendered obsolete.

The tendency of failing to take timely action in defusing the conflicts is blamed for the land conflict existing at the Emboley Murtangos CBNRM in Kiteto whereby politicians, civil servants and farmers have been implicated. Pastoralists in Kiteto district revealed that keeping a blind eye on land grabbing practices by the government prompted their rebellion against the land grabbers after several attempts of removing the invaders from their land amicably and through legal procedures proved futile. A plausible explanation for the reluctance of taking timely action is due to conflict

${ }^{6}$ FDG on 31/7/2015 in Kimana village, Kiteto district over the role of local leadership in conflict management. of interests, among government officials who are directly involved in natural resource use planning and management. These findings are consistent with findings from other studies on land grabbing done elsewhere. According to Ref. [48], weak land management institutions and lack of enabling legislations are responsible for large-scale land grabbing in South Sudan. Scott [49] argue further that land grabbing at the global level is attributed to various mechanisms ranging from straight forward private-private purchases and public-private leases for biofuel production. Similarly, FAO [50] point out that land grabbing has been escalated by alliances between state officials, local political elites and domestic and foreign investors and thus opening up opportunities for these investors to appropriate scarce resources. The stated alliances provide further opportunities for these investors of extending their reach, exerting power over marginal areas and people, as well as extracting rent from such "unruly" practices.

In Kiteto district, the respondents reported four drivers of land grabbing, first is the urban affluent population which has bought and hold more land for speculative reasons; second, land alienation for conservation purposes; third, increased demand for land among local investors; fourth, the vice of corruption among village government officials who get involved in illegal land transactions to the affluent urban population without following normal land 
allocation procedures as stipulated in the Land Act No. 4 of 1999 and the Village Land Act No. 5 of 1999. These findings suggest that land grabbing has propagated a seed of hatred among farmers and pastoralists, thus, leading to deadly conflicts between the two land use groups. According to Kiteto district security records, the 2014 deadly conflicts between farmers and Maasai pastoralists led to the death of more than 50 people out of these, 34 deaths occurred at the Emboley Murtangos CBNRM area whereby the majority of the victims were casual labourers. People of various age groups were also killed including a 70 year old man, three infants and five women. In the incident, over 2,000 cows were stolen. These conflicts were reported to have been planned and they were thus considered as an organised crime against innocent people ${ }^{7}$. The above view was echoed by farmers who revealed that "...the conflicts were not spontaneous in nature but rather they seem to have been strategically planned by a group of influential individuals including wealthy livestock keepers, Maasai traditional leaders 'Ilaigwanak' and some government officials with some political agenda ${ }^{8}$ ".

The farmers argument is based on the fact that nobody within the mentioned category of individuals took the initiatives early enough to halt the situation; rather they all were inactive while the tension between the parties in conflicts was getting worse until the situation ran out of control. Seven villages were reported to have fallen victims of a rapid influx of farmers from outside the region. The so called "invaders" were poor people who were deployed by 78 prominent wealthy politicians, businessmen and civil servants living far away in commercial urban centres. The invaders occupied approximately 63,740 ha, equivalent to $47.8 \%$ of the CBNRM where most of the people lost lives. Farmers reported further that

\footnotetext{
${ }^{7}$ Interview with a senior security officer in Kiteto district, August 3, 2015.

${ }^{8}$ Farmers responses during an informal discussion held at Mbeli a sub-village (hamlet) of Kimana village, Partimbo ward in Kiteto district on July 30, 2015.
}

pastoralists, who were enjoying government's support, were issued with a letter which directed them to solicit funds to be used to evict the invaders from the community conservation land. Further consultations with different stakeholders, established that the government eviction order $^{9}$ of removing all land grabbers from Emboley Murtangos CBNRM was lawful and farmers were just using the fund raising directive as a scapegoat of protesting against the court of appeal ruling ${ }^{10}$ with the aim of tarnishing government image. According to the study findings, the unlawful establishment of settlements within the CBNRM took place at Kuti, Silalei, Orkeri, Latimi, Kwa Mtanzania, Kwa Kibumu, Seseni, Majengo, Pori Kwa Pori, Kisima 1 and Kisima $2^{11}$.

Farmers' establishment of permanent houses within the conserved land further signifies lack of resolve by the relevant authorities in enforcing the existing law. The houses were demolished by the district council following the appeal by the appellant Kiteto District Council which was granted the powers to evict the invaders. In fact, records show that the first lawful order was issued in 2011 and the second in 2013 but none of these was implemented until 2014. Individuals' noncompliance to lawful orders seemed to have triggered the impatient Maasai pastoralists' anger which led into the launching of the unprecedented deadly attacks against the farmers, mostly innocent casual labourers working on the farms which were grabbed within the community conservation area. Despite the early warning signs of what would turn out to be deadly conflicts between farmers and pastoralists', traditional leaders and local government officials were rather inactive in mitigating

\footnotetext{
${ }^{9}$ Kumb.Na.HMW/KY/R/09/35,12/12/2011 from Jane K. Mutagurwa, district executive director, Kiteto, to village chairman, Kimana village.

${ }^{10}$ Civil appeal No. 58 of 2010 in Land Case No. 6 of 2004 in the Land Division of the High Court of Tanzania at Dar es Salaam of which Kiteto District Council was the appellant \& Tito Shumo and 49 others respondents (judgment of the court September 5 and November 10, 2011).

${ }^{11}$ Researchers' own observation of the demolished houses following the government directives.
} 
the conflicts. This implies that there was a conflict of interest among community leaders on land matters at Emboley Murtangos and, thus, effectively or implicitly making them part of the land grabbing plan.

\subsubsection{Excessively Large Herds of Cattle}

Excessively large herds of cattle had an eigen value of 1.188 , and it was mentioned by more than two thirds (69.7\%) of the respondents as one of the drivers of farmers-pastoralists resource use conflict in the study area. A study by Msigwa and Mvena [22] reported an association between large livestock population beyond a land's carrying capacity and conflicts in Ngorongoro and how it negatively affects lives of local communities. The study findings indicate that land grabbing and invasion of farmers at Emboley Murtangos in Kiteto district had reduced pastureland leading to a concentration of pastoralists into smaller areas that could no longer support their livestock. As a result, there was an increase in the incidences of natural resource use conflicts between farmers and pastoralists.

According to the study findings, Godes sub-village/hamlet in Majambaa village was a typical case of excessive livestock population surpassing land carrying capacity in Kilosa district. The area had 5,000 ha of land that was designated for pastoralists in 1997. Within the sub-village, there were 39 Maasai kraals, each having approximately 150 herds of cattle, thus, a total of 5,850 cattle $^{12}$ were recorded in the sub-village. According to Refs [51, 52], stocking rates are measured in tropical livestock units (TLUs)/ha. The TLU is a standardized animal unit obtained by multiplying the number of animals with a conversion factor that takes into account "feed requirement" for the animals [52]. Therefore, Godes might be a typical example of an area with an excessive number of livestock where the recommended number is 3,500 cattle. Ref. [52] shows that the TLU in sub-Saharan Africa is 0.7. Therefore, the current estimate of the

\footnotetext{
${ }^{12}$ Interview with a 63 year old Maasai elder on 24/9/2015 at Majambaa village Kilosa district.
}

number of livestock in Godes is 1.17 TLU/ha thereby exceeding the land carrying capacity by $0.47 \mathrm{TLU} / \mathrm{ha}$, which is equivalent to 2,340 cattle. In this respect, inadequate pastures forced livestock to graze outside the designated areas adjacent to the farms hence predisposing crops to livestock damage, and thus driving farmers and pastoralists into natural resource use conflicts. According to Ref. [52], the number of ruminant livestock is increasing to such high levels that some livestock stock in some countries appears to have exceeded the carrying capacity of the land, thus leading to exceptionally high pressure on the limited resources leading to the eruption of overt conflicts. According to Ref. [51], the current total livestock unit (TLU) per hectare in sub-Saharan Africa is between 0.48-0.75 TLU/ha; this indicates that in some parts, livestock numbers fall below the recommended number per unit area while in others they exceed the land carrying capacity.

\subsubsection{Pastoralists Corrupting Government Officials}

The study results further show that the tendency of pastoralists to corrupt government officials was another driver of conflicts. Oral testimonies from the respondents showed that corruption was widespread among the police who in most cases were alleged to be colluding with the farmers to obtain money illegally from the pastoralists. The police were reported to be the source of the farmers-pastoralists conflicts as they receive bribes from both sides and thereby failing to dispense justice due to a conflict of interest ${ }^{13}$. These results are supported by Benjaminsen et al. [2]. According to a quote from an interview conducted in Kilosa in 2009, the respondents had these to say:

"Corruption is another reason for the conflict between farmers and pastoralists in Kilosa district. For instance, if my cattle are caught by farmers, grazing in their farms, the cattle would be taken to the village office so that the farmer can get be compensated.

\footnotetext{
${ }^{13}$ An oral testimony from a male farmer aged 45 years in Kilosa.
} 
Alternatively, I can give money to the authorities to return the cattle to me without compensating the farmer”"14.

Cases of corruption are complicated by village leaders who are not faithful. They receive bribes from pastoralists and allow them to graze their livestock on land which was not designated for grazing.

On their part, pastoralists use their economic power to bribe magistrates and the police instead of compensating the farmers whose crop have been damaged $^{15}$. This suggests that denial of a person's right through corruption, leads to hatred against the offender, thus escalating the likelihood of revenge among conflicts actors. This is considered to be a plausible reason for increasing cases of intentional injuring and killing of livestock by farmers in Kilosa. Once the livestock have been killed, pastoralists react by taking the law on their hands against the act thus complicating the situation even further. According to Ref. [53], local leaders in Senegal abused rules in order to solicit bribes from the parties in a conflict which ends up in deepening the conflicts. Likewise, Umar et al. [54] reported that in Nigeria corruption is committed by local leaders through overestimation of the number of crops damaged by livestock in order to be given some amount of money by farmers as bribes.

\section{Conclusions and Recommendations}

Conflicts between farmers and pastoralists are widespread and affect millions of people in sub-Saharan Africa every year. In view of the study findings, the various forms and drivers of conflicts are, to a large extent, a product of failure by the law enforcement agents in observing rules and regulations in resource use management in the study areas. The most notable forms of conflicts are the intragroup and intergroup conflicts occurring among and between farmers versus pastoralists, triggered by dispute

\footnotetext{
${ }^{14}$ Response from a pastoralist interviewed in Kilosa by Benjaminsen et al. in 2009.

${ }^{15}$ Verbal testimony from a senior agricultural officer in Kilosa district interviewed on 6/10/2015.
}

around village boundaries, blockage of livestock routes as well as the double allocation of land to more than one person. With regard to the drivers of conflicts, government officials, reluctance to timely take action in managing conflicts and corruption reflect the extent of moral degeneration among the people in the studied areas. Moreover, these tendencies account for the failure among those entrusted with the responsibility of sensibly and ethically managing the resources in order to reduce the conflicts.

Based on the study findings and conclusions it is recommended that the government through the Ministry of Agriculture and Ministry of Livestock and Fisheries should ensure that pastoralists are provided with the essential services such as water in order to minimize movement of their herds of livestock from their designated villages to other areas in search for water. This would, as a result, minimize farmers' crop damage which has been a major source of conflict. Moreover, land carrying capacity studies should be carried out to determine appropriate land carrying capacity of rangelands in order to maintain the right numbers of livestock that would not put excessive pressure on the available grazing resources. The Kilosa and Kiteto District Councils should establish land use plans to minimize resource use conflicts between different land users. The district councils in the study areas should formulate bylaws for controlling livestock populations in areas with limited land in order to match with the land carrying capacity. The alleged corrupt practices and the reluctance among government officials of taking action in time in conflict affected areas should be investigated by the relevant authorities such as the Prevention and Combating of Corruption Bureau (PCCB) in order to identify the source of these vices and institute legal procedures/actions against the offenders.

\section{References}

[1] Gefu, J. O., and Kolawole, A. 2002. "Conflict in Common Property Resource Use: Experiences from an Irrigation Project.” In Proceedings of the 9th Biennial Conference of the International Association for the Study 

Kilosa and Kiteto Districts, Tanzania

of Common Property (IASCP), 16.

[2] Benjaminsen, T. A., Maganga, F. P., and Abdallah, J. M. 2009. "The Kilosa Killings: Political Ecology of Farmer-Herder Conflict in Tanzania.” Dev. and Ch. 40 (3): 423-55

[3] Kircher, I. 2013. Challenges to Security, Livelihoods, and Gender Justice in South Sudan: The Situation of Dinka Agro-pastoralist Communities in Lakes and Warrap States. Oxfam, London, 50.

[4] Wood, R. M. 2010. "Rebel Capability and Strategic Violence against Civilians.” J. of Pe. Res. 47 (5): 601-14.

[5] Brehony, E., Morindat, A. O., and Sakafu, A. 2003. A Study on Conflicts between Pastoralists and Farming Communities, Kilosa District, Morogoro Region, Tanzania. Report for Kilosa District Council, 16.

[6] Ubwani, Z. 2014. "Why Land Clashes Continue Unabated in Kiteto District.” The Citizen 23 (1): 71-4.

[7] Benjaminsen, T. A., Maganga, F. P., and Abdallah, J. M. 2014. Farmer-Pastoralists Conflicts in Tanzania: What Can Be Done? Farmers-Pastoral Conflicts, Policy Brief No. 1. The Sokoine University of Agriculture, Morogoro, Tanzania, 5.

[8] Ubwani, Z. 2014. "Economic Cost of Kiteto Land Crisis.” The Citizen. Accessed July 28, 2015. http://www.thecitizen.co.tz/News/national/Economic-cost -of-Kiteto-land/ index. html.

[9] Askew, K., Maganga, F., and Odgaard, R. 2016. “Terms of Use of Land and Legitimacy: A Tale of Two Lawsuits of Land and Legitimacy." Cambridge Journal 83: $120-41$

[10] Hakiardhi. 2009. "The State of the then NAFCO, NARCO and Absentee Landlords Farms/Ranches in Tanzania.” Accessed August 4, 2014. www.iwgia.org/iwgiafilespublications.pdf.

[11] URT. 2015. “Ministry of Livestock and Fisheries Development Tanzania Livestock Modernization Initiative.” Accessed December 21, 2016. http://www.livestocklivelihood.pdf.

[12] Makoye, K. 2014. "Tanzania Struggle to End Clashes between Farmers and Herders.” IPS News Agency, Dar es Salaam. Accessed November 14, 2014. http:www.ipsnews.net/2014/01/tanzania-finds-hard-stop-f armers-herders-fighting-resources/.

[13] Tenga, R. 2011. "Seeking Redress from Courts of Law by Pastoralists in Tanzania." In Proceedings of the Conference on Half a Century of Struggles by Pastoralists for Land Rights: Examining Achievements, Challenges and the Proposed New Constitution as a Window of Opportunity, organized by the Association for Law and Advocacy for Pastoralists (ALAPA) and PINGOs Forum, Arusha, 24-5.

[14] King, N. A. S. 2013. "Conflict Management among the
Farmers and Pastoralists in Tanzania." International SAMANM Journal of Business and Social Sciences 1 (2): 40-50.

[15] Tenga, R., Mattee, A., Mdoe, N., Mnenwa, R., Mvungi, S., and Walsh, M. 2008. "A Study on Options for Pastoralists to Secure Their Livelihoods in Tanzania.” In Current Policy, Legal and Economic Issues, Vol. 1: Main Report. For CORDS, PWC, IIED, MMM, TNRF, and UCRT. Dar es Salaam, 113.

[16] Kajembe, G. C., Mbwilo, A. J., Kidunda, R. S., and Nduwamungu, J. 2003. "Resource Use Conflicts in Usangu Plains, Mbarali District, Tanzania.” International Journal of Sustainable Development and World Ecology 10 (4): 333-43.

[17] Kisoza, A. J. L. 2007. "The Role of Local Institutions in the Management of Agro-pastoral and Pastoral Systems: A Case Study of Mkata Plains, Kilosa District and Ngorongoro Conservation Area, Ngorongoro District, Tanzania.” Ph.D. thesis, Sokoine University of Agriculture, Morogoro, Tanzania, 457.

[18] Saruni, L. P. 2011. "Governance in Resource Use and Conflict in Simanjiro District, Tanzania.” Kiv. J. 1: 91-106.

[19] Mwamfupe, D. 2015. "Persistence of Farmers-Herders Conflicts in Tanzania." International Journal of Scientific Research 5 (2): 339-46.

[20] Domasa, S. 2016. "Panel Ends Investigations into Morogoro Village Land Dispute.” Daily News. Accessed August 4, 2014. https:www.newsafrica.com.

[21] Lawuo, Z. A., Mbasa, B., and Mnyawi, S. 2014. "Persistence of Land Conflicts between Maasai Community and Ngorongoro Conservation Area Authority in Ngorongoro Conservation Area.” Inter. J. of Inno. and Sci. Res. 5 (2):154-61.

[22] Msigwa, G. B., and Mvena, Z. S. K. 2014. "Change in Livelihoods of Evicted Agro-pastoralists from Ihefu Basin in Tanzania.” Liv. Res. Rur. Dev. 26 (1): 1-11.

[23] Krug, R. S., and Cass, A. R. 2012. Behavioral Sciences. New York: Springer Science \& Business Media, 323.

[24] Edewor, P. A., Aluko, Y. A., and Folarin, S. F. 2014. "Managing Ethnic and Cultural Diversity for National Integration in Nigeria.” Dev. Country Stu. 4 (6): 70-6.

[25] Folarin, S. F. 2015. "Types and Causes of Conflict." Covenant University, Ota, 1-12.

[26] Mpangala, P. G., and Mwansasu, U. B. 2004. Beyond Conflict in Burundi. The Mwalimu Nyerere Foundation, Dar es Salaam, 410.

[27] Bernauer, T., Böhmelt, T., and Koubi, V. 2012. "Environmental Changes and Violent Conflict." Environmental Research Letters 7 (1): 015601. https://iopscience.iop.org/article/10.1088/1748-9326/7/1/ 015601/pdf. 

Kilosa and Kiteto Districts, Tanzania

[28] Homer-Dixon, T. F. 2010. Environment, Scarcity, and Violence. New Jersey: Princeton University Press, 253.

[29] Barnett, J., and Adger, W. N. 2007. "Climate Change, Human Security and Violent Conflict.” Pol. Geo 26 (6): 639-55.

[30] Collier, P., and Hoeffler, A. 1998. "On Economic Causes of Civil War.” Oxford Economic Papers 50 (4): 563-73.

[31] De Soysa, I. 2002. "Paradise Is a Bazaar? Greed, Creed, and Governance in Civil War, 1989-99.” Journal of Peace Research 39 (4): 395-416.

[32] PAICODEO. 2013. "Report on the State of Pastoralists' Rights in Tanzania: Survey of Ten Districts of Tanzania Mainland 2010/2011.” IWGIA, Copenhagen, 98.

[33] United Republic of Tanzania (URT). 2011. "Statistical Abstract 2011.” NBS, Ministry of Finance, Dar es Salaam, 153. istmat.info/files/uploads/52669/statistical.pdf.

[34] United Republic of Tanzania (URT). 2016. "Statistical Abstract 2017.” NBS, Ministry of Finance, Dar es Salaam, 106. istmat.info/files/uploads/statistical.pdf.

[35] Coulibaly, Y. J., Mango, J., Swamila, M., Tall, A., Kaur, H., and Hansen, J. 2015. "What Climate Services Do Farmers and Pastoralists Need in Tanzania? Baseline Study for the GFCS Adaptation Program in Africa.” Working Paper No. 110. Climate Change, Agriculture, and Food Security, Copenhagen, Denmark, 42.

[36] Babbie, E. R. 2013. The Basics of Social Research. Wadsworth Cengage Learning, Belmont, 545.

[37] Rubin, A., and Babbie, E. R. 2016. Empowerment Series: Research Methods for Social Work. Cengage Learning, Belmont, 651.

[38] URT. 2013. Population and Housing Census Population: Population Distribution by Administrative Areas. National Bureau of Statistics, Dar es Salaam, 264.

[39] Kothari, C. R. 2004. Research Methodology; Methods and Techniques, 2nd ed., New Age International (P) Ltd., New Delhi, 418.

[40] Bryman, A. 2004. Social Research Methods. Oxford: Oxford University Press, 592.

[41] Mutayoba, V. 2011. "Potentials of Vanilla Production as an Alternative Cash Crop: The Case of Bukoba District Tanzania.” J. Mwl. Ny. Ml. Ac. 1 (1): 132-48.

[42] Kisoza, L. J. A. 2014. "Empirical Analysis of Resource-Use Conflicts between Smallholder Farmers and Pastoralists in Semi-arid Areas: A Case of Mkata Plains, Eastern Tanzania.” J. O. U. of Tan. 1 (16): 104-17.
[43] Kisoza, L. J. A., Kajembe, G. C., and Monela, G. C. 2004. "Natural Resource Use Conflicts in Kilosa District, Morogoro Region, Tanzania.” In Proceedings of the International Food Policy Research Institute East African Regional Conference, Institutions, Incentives, and Conflicts in Forest Management. Nairobi, 108-23.

[44] Abbass, I. M. 2014. "No Retreat No Surrender Conflict for Survival between Fulani Pastoralists and Farmers in Northern Nigeria.” Eur. Sci. J. 8 (1): 91-105.

[45] Mkonda, M. Y. 2016. "The Political Ecology of Peasant-Herder Conflict in Mvomero District, Tanzania.” Journal of Advance in Social Science and Humanities 2 (12). http://dx.doi.org/10.15520/jassh212153.

[46] Kirk, M. 1999. "The Context for Livestock and Crop-Livestock Development in Africa.” In The Evolving Role of the State in Influencing Property Rights Over Grazing Resources in Sub-Saharan Africa, edited by McCarthy, N., Swallow, B., Kirk, M., and Hazell, P. International Food Policy Research Institute, Washington, D.C., 447.

[47] Pantuliano, S. 2007. The Land Question: Sudan's Peace Nemesis. HPG, ODID, London, 14.

[48] Hall, R. 2011. The Many Faces of the Investor Rush in Southern Africa: Towards A Typology of Commercial Land Deals, Working Paper Series No. 2. International Institute of Social Studies, The Hague, 32.

[49] Scott, J. C. 2010. The Art of Not Being Governed: An Anarchist History of Upland Southeast Asia. Nus Press.

[50] FAO. 2005. Statistical Yearbook of the Food and Agricultural Organization for the United Nations. FAO. Accessed July 26, 2015. http://www.fao.org/docrep/pdf.

[51] Pica-ciamarra, U., Otte, J., and Chilonda, P. 2007. "Land and Rural Conflicts in Sub-Saharan Africa.” Liv. Pol. 7: 1-20.

[52] FAOSTAT. 2015. World Food and Agriculture Statistical Pocket Book. Food and Agricultural Organisation, Rome, Italy, 236.

[53] Abroulaye, S., Issa, S., Abalo, K. E., and Nouhoun, Z. 2015. "Climate Change: A Driver of Crop Farmers-Agro Pastoralists Conflicts in Burkina Faso.” International Journal of Applied Science and Technology 5 (3): 1-13.

[54] Umar, S., Umar, B. F., and Illo, A. I. 2013. "Coping Strategies among Farmers and Herders during Post Conflict Situation in the Kainji Dam Area of Yauri Emirate, Kebbi State Nigeria.” J. of Edu. and Soc. Res. 3 (9): 59-65. 


\section{Appendix 1: Sample size determination formula:}

$$
n=\frac{Z^{2} p q N}{e^{2}(N-1)+Z_{\alpha / 2}^{2} p q}
$$

where $n$ is the sample size for the finite population. $N$ : size of the universe population of the community being studied, $p$ : population reliability or frequency estimated for a sample size $(n)$, where $p$ is 0.5 which is taken for all developing countries population and $p+$ $q=1, e$ : margin of error considered is $5 \%$ for this study. $Z_{\alpha / 2}$ : normal reduced variable at 0.05 level of significance $Z$ is 1.96 . According to the above formula, the sample size for all two districts Kilosa and Kiteto were expected to be:

$$
n-\frac{N(\text { ward }) \times n(\text { allwards })}{N(\text { allwards })} n=\frac{(1.96)^{2} \times 0.5 \times 0.5 \times 84336}{0.05^{2} \times(84336-1)+\left[(1.96)^{2} \times 0.5 \times 0.5\right]}=382 \text { households } \quad \text { (2) [39] }
$$

where $n$ is the sample size at ward level, $N$ (ward) is the individual number at ward level [(Kilosa $=45,687)($ Kiteto $=38,649)], n$ (allwards) is the sample size of the study wards (382). $N$ (allwards) is the individuals' number of all wards through which the survey was conducted $(84,336)$. 